\title{
Biochemical and cytological characterization of wheat/Aegilops ventricosa addition and transfer lines carrying chromosome $4 \mathrm{M}^{\mathrm{v}}$
}

\author{
M. Mena, J. Orellana, I. Lopez-Braña, F. García-Olmedo and A. Delibes \\ Programa de Biotecnologia Agroforestal, E.T.S. Ingenieros Agrónomos, E-28040 Madrid, Spain
}

\begin{abstract}
Summary. The gene encoding a variant of alcohol dehydrogenase, $A d h-\mu$, has been found to be associated with the chromosome of the $\mathrm{M}^{\mathrm{v}}$ genome which is present in type 9 wheat/Aegilops ventricosa addition line, to which the genes for protein CM-4 and for a phosphatase variant, Aph-v, had been previously assigned. Transfer line $\mathrm{H}-93-33$, which has 42 chromosomes and has been derived from the cross (Triticum turgidum $\times$ Ae. ventri$\cos a) \times T$. aestivum, carries genes encoding all three biochemical markers. Linkage between these genes has been demonstrated by analysis of individual kernels of the $F 2$ (H-93-33 $\times$ T. aestivum $\mathrm{cv}$. "Almatense" $\mathrm{H}-10-15)$. A study of the hybrids of line $\mathrm{H}-93-33$ with $T$. aestivum H-10-15 and with the 4DS ditelosomic line has confirmed that, as suspected, the linkage group corresponds to chromosome $4 \mathrm{M}^{v}$ from Ae. ventricosa. Additionally, it has been found that the previously reported resistance of line H-93-33 to powdery mildew (Erysiphe graminis) is also linked to the biochemical markers; this indicates that either the gene responsible for it is different from that in lines $\mathrm{H}-93-8$ and $\mathrm{H}-93-35$, or that a translocation between two different $\mathrm{M}^{\mathrm{v}}$ chromosomes has occurred in line H-93-33.
\end{abstract}

Key words: Wheat - Aegilops ventricosa - Powdery mildew resistance - Biochemical markers - Addition and transfer lines

\section{Introduction}

The wild grass Aegilops ventricosa (syn. Triticum ventricosum) has been long recognized as a potential source of genes for resistance to fungi, insects and nematodes (Sprague 1936; Delibes et al. 1977a, b; Dosba and Doussinault 1977). Some of these genes, such as those conferring resistance to the eyespot disease (Pseudocercosporella herpotrichoides) and powdery mildew (Erysiphe graminis), have been already successfully transferred to the cultivated wheat Triticum aestivum (Delibes et al. 1977 a, 1981, 1987; Doussinault et al. 1983; GarciaOlmedo et al. 1984), while work is in progress to further exploit Ae. ventricosa as a donor of useful agronomic traits. In this context, a considerable effort has been devoted to develop addition lines carrying Ae. ventricosa chromosomes in a wheat background (Dosba and Doussinault 1978; Delibes et al. 1981; Dosba 1985) and to obtain substitution and transfer lines (Delibes and Garcia-Olmedo 1973; Delibes et al. 1977 b; Doussinault et al. 1983; Garcia-Olmedo et al. 1984), which are useful stocks in the manipulation of the resistance genes. Ae. ventricosa is an allotetraploid with a genomic constitution $D^{v} D^{v} M^{v} M^{v}$ which is partially homologous to that of $T$. aestivum (AABBDD), so that genes from the $\mathrm{D}^{v}$ genome are more easily transferred by recombination with the $D$ genome than those from the homoeologous $M^{v}$ genome (Delibes et al. $1977 \mathrm{~b}$ ). Addition lines involving $\mathbf{M}^{v}$ chromosomes were established on the basis of cytological, morphological and agronomical characters by Dosba et al. (1978) and tentative identification of these lines was undertaken through the use of biochemical chromosome markers (Delibes et al. 1981; for review, Dosba 1985).

In a separate study, a different accession of Ae, ventricosa was used to derive wheat lines with 42 chromosomes carrying genetic material from both the $D^{v}$ and the $\mathbf{M}^{v}$ genomes (Delibes and Garcia-Olmedo 1973; Delibes et al. 1977 a, b; Doussinault et al. 1983; Garcia-Olmedo et al. 1984). In this report, we confirm the identification of the addition line carrying chromosome $4 \mathrm{M}^{v}$ and characterize a transfer line carrying the genetic markers of that chromosome. 
A

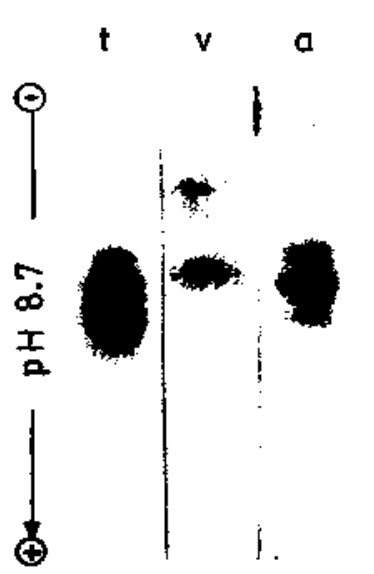

Addition lines type

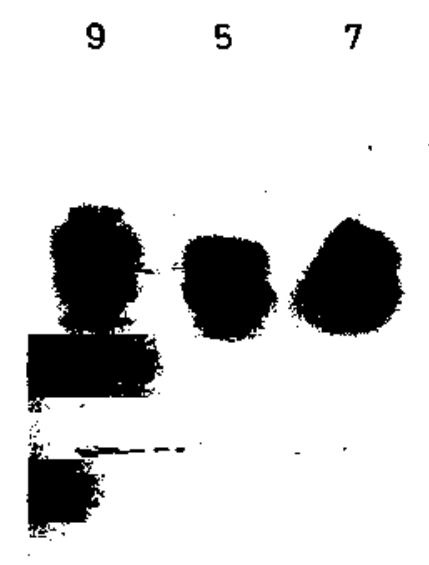

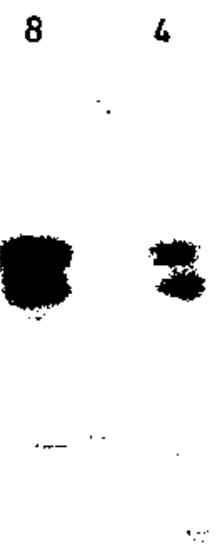

B

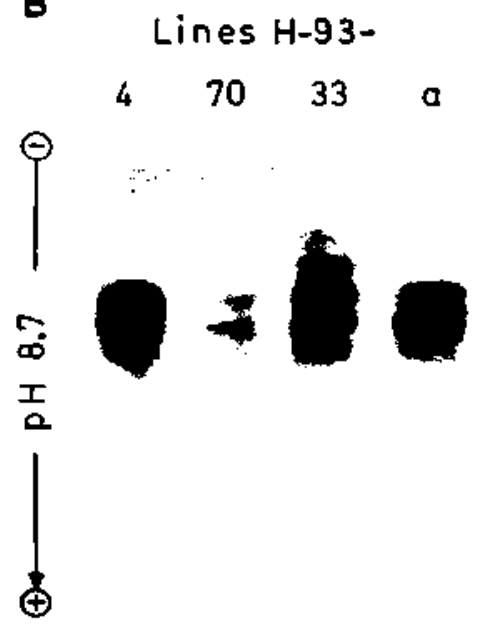

Fig. $1 \mathrm{~A}$ and B. Alcohol-dehydrogenase isozyme patterns in endosperm extracts; $\mathbf{t}-T$. turgidum; $\mathbf{v}-$ Ae. ventricosa; a-T. aestivum. Wheat/Ae. ventricosa addition lines are in Ae. ventricosa cytoplasm (Dosba 1985). Transfer lines H-93 have 42 chromosomes (Delibes and Garcia-Olmedo 1973; Delibes et al. 1977b)

\section{Materials and methods}

\section{Biological material}

Wheat/Ae. ventricosa addition lines with Aegilops cytoplasm were obtained by crossing (Ae. ventricosa no. $11 \times T$. aethiopicum) $\times T$. aestivum cv. "Moisson" and self-pollinating five or six times (Dosba et al. 1978: Dosba 1985). Those with wheat cytoplasm were similarly derived from the cross ( $T$. aestivum $\mathrm{cv}$. "Moisson" $\times$ Ae. ventricosa no. 11) $\times T$. aestivum cv. "Moisson" (Dosba et al. 1978; Dosba 1985).

The hexaploid $\mathrm{H}-93$ lines, derived from the cross ( $T$, turgidum H-1-1 × Ae. ventricosa AP-1) $\times$ T. aestivum cv. "Almatense" $\mathrm{H}-10-15$, have been also previously described (Delibes and Garcia-Olmedo 1973; Delibes et al. 1977b).

\section{Biochemical markers}

Protein CM-4 was analysed by electrophoresis of the chloroform:methanol $(2: 1, v / v)$ extract as previously described (Delibes et al. 1981). Phosphatase isozymes from wheat kernels were extracted fractionated and stained in the alkaline conditions of Brewer (1970), as described by Delibes et al. (1981). Isozymes of alcohol dehydrogenase were investigated as in Hart (1970), except that the samples were extracted in an ultrasonic bath for 2 min and centrifuged in a Beckman Microfuge for $1 \mathrm{~min}$.

\section{DNA hybridization}

Genomic DNA was isolated from 7 day-old dark-grown seedlings essentially as described by Murray and Thompson (1980). Restriction digestion, agarose gel electrophoresis and Southern blotting to nylon membranes (Hybond N, Amersham) were performed according to Maniatis et al. (1982) and to the manufacturers instructions. A maize probe for alcohol dehydrogenase was supplied by $M$. Freeling (Bennetzen et al. 1984). The probe was made radioactive by the oligo-labelling method (Feinberg and Vogelstein 1983), hybridized overnight at $65^{\circ} \mathrm{C}$ and washed twice at $50^{\circ} \mathrm{C}$.

\section{Cytological procedures}

Meiotic chromosomes were analysed, after fixing the anthers in acetic-ethanol $1: 3$ at $4^{\circ} \mathrm{C}$ for 2 months, by squashing the cells and staining following the Giemsa $\mathrm{C}$-banding technique.

\section{Results and discussion}

Association of a gene for alcohol dehydrogenase $(A d h-\mu)$ with type 9 addition lines

Five different types of wheat/Ae, ventricosa addition lines were established by Dosba et al. (1978) on the basis of cytological, morphological and agronomical characters, both in $v$ (Ae. ventricosa) and $\mathrm{m}$ ( $T$. aestivum) cytoplasms. A protein marker (CM-4) and a phosphatase isozyme (Aph-v) were found to appear concomitantly in $v$ and $m$ lines of type 9 (type $D$ in Dosba et al. 1978), lending further support to the classification, which was more difficult for the $m$ lines because the non-biochemical characters discriminating type 9 were less clearly expressed in the wheat cytoplasm (Delibes et al. 1981). These results also suggested that the added chromosome in type 9 addition lines was $4 \mathrm{M}^{\mathrm{v}}$, because protein CM-4 had been indirectly associated with group 4 chromosomes (Delibes et al. $1977 \mathrm{~b}$ ), and genes encoding phosphatase isozymes have been found in chromosomes of the same homoeology group (Brewer et al. 1969).

To seek additional evidence for this hypothesis, isozyme patterns for alcohol dehydrogenase (Adh), which are controlled by group 4 chromosomes in wheat (Hart 1970), were analysed in the wheat/Ae. ventricosa addition lines and in their parental material (Fig. 1 A). The Adh 
isozyme pattern of Ae. ventricosa stained weakly and consisted of three faint bands. These bands would correspond to a homodimer/heterodimer/homodimer pattern as postulated for other alloploids (Hart 1970). Expression of the gene encoding the subunit of the slowest homodimer from Ae, ventricosa $(A d h-\mu)$ should be detectable in the wheat background by the appearance of two extra bands, respectively corresponding to this homodimer and to the heterodimer with the subunit of the slowest wheat homodimer. In agreement with the proposed identity of the added chromosome of Ae, ventricosa, the expected Adh pattern was exclusively found in type 9 addition lines (Fig. 1A). As with the nonbiochemical characters, a higher level of expression was detected with the $v$ cytoplasm than with the $m$ one (not shown).

\section{Linkage of putative markers of chromosome $4 M^{v}$} in transfer line $\mathrm{H}-93-33$

Wheat/Ae. ventricosa transfer lines with 42 chromosomes (H-93-1 to H-93-70), derived by crossing the donor species, Ae, ventricosa (genomes $\mathrm{D}^{r} \mathrm{D}^{r} \mathrm{M}^{\mathrm{v}} \mathrm{M}^{\mathrm{v}}$ ), with $T$. turgidum (AABB), which acted as a bridge, and rescuing the sterile $A B D^{v} M^{v}$ hybrid with pollen from the recipient species, T. aestivum (AABBDD), have been previously described (Delibes and Garcia-Olmedo 1973; Delibes et al. 1977 b). Putative biochemical markers of chromosomes from the $\mathrm{M}^{\mathrm{v}}$ genome, which had been selected on the basis of their presence in Ae. ventricosa $\left(\mathrm{D}^{v} \mathrm{D}^{v} \mathrm{M}^{v} \mathrm{M}^{v}\right)$, Ae comosa $(\mathrm{MM})$ and Ae. uniaristata $\left(\mathrm{M}^{\mathrm{u}} \mathrm{M}^{\mathrm{u}}\right)$, generally appeared at low frequencies $(<4 \%)$ in the $\mathrm{H}-93$ lines, with the exception of marker CM-4, which was present at the high frequency $(\sim 30 \%)$ expected of markers of $D^{v}$ chromosomes (Delibes et al. 1977 b).

Line H-93-33 was the only transfer line carrying the phosphatase marker Aph-v and one among those carrying marker CM-4. Linkage of the two markers was demonstrated by analysis of individual kernels of the $F 2$, $\mathrm{H}-93-33 \times T$. aestivum $\mathrm{H}-10-15$ (Table 1 ). This indicated that the independent distribution of CM-4 among the H-93 lines must have resulted from an early recombination event during the gene transfer process and that the genes for the two markers must have originally resided in the same chromosome, as observed in the independently derived addition lines.

The Adh system was investigated in the $\mathrm{H}-93$ lines both by the zymogram technique and by Southernblotting with a heterologous Adh probe from maize. Line H-93-33 was again the only one showing the two additional isozyme bands controlled by Adh- $\mu$ (Fig. 1 B). Southern-blot hybridization of DNA digested with the appropriate restriction enzymes also allowed the identification of a DNA fragment specific for Ae. ventricosa. which was present in $\mathrm{H}-93-33$ but not in the other lines

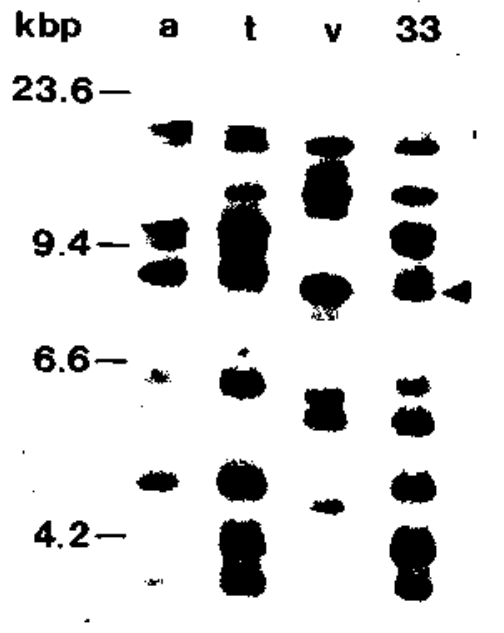

Fig. 2. Southern-blot analysis of DNAs digested with the Hind IIl restriction endonuclease from the following stocks: a$T$. aestivum; $\mathrm{t}-T$. turgidum; $\mathrm{v}-A$ Ae. ventricosa, (33) transfer line H-93-33. The probe used was a $2.3 \mathrm{kbp}$ Hind III fragment subcloned (pB428) from a maize alcohol dehydrogenase gene by Bennetzen et al. (1984) and was labeled with $\left[\alpha-{ }^{32} \mathrm{P}\right] \mathrm{dATP}$ by the method of Feinberg and Vogelstein (1983). The horizontal arrowhead points to a hybridization band specific for Ae. ventricosa which appears exclusively in line $\mathbf{H}-\mathbf{9 3}-33$

Table 1. Linkage of genes for protein CM-4, alcohol dehydrogenase isozyme Adh- $\mu$, phosphatase isozyme Aph-v, and resistance to powdery mildew $(\mathrm{Pm})$ in the $F 2$ between the transfer line H-93-33 (Aph-v ${ }^{+}, \mathrm{CM}^{+}, \mathrm{Adh}-\mu^{+}, \mathrm{Pm}^{-}$) and $T$. aestivim $\mathrm{H}-10-15$

\begin{tabular}{|c|c|c|c|c|c|c|}
\hline \multirow[t]{3}{*}{ Aph-v ${ }^{a}$} & \multicolumn{6}{|c|}{ No. of plants } \\
\hline & \multicolumn{2}{|c|}{ CM4 } & \multicolumn{2}{|c|}{ Adh- $\mu$} & \multicolumn{2}{|c|}{$\mathbf{P m}^{2}$} \\
\hline & + & - & + & - & $I$ & s \\
\hline+ & 106 & 0 & 84 & 0 & 43 & 3 \\
\hline- & 3 & 38 & 0 & 38 & 2 & 16 \\
\hline
\end{tabular}

a + present; - absent; r resistant; s susceptible

(Fig. 2). Additionally, several bands showed altered hybridization intensity with respect to $T$. aestivum and $T$. turgidum. Linkage between Adh $\mu$ and the phosphatase marker Aph-v was also demonstrated by analysis of the individual F2 kernels, thus confirming that the three markers associated with the putative $4 \mathrm{M}^{*}$ chromosome in addition lines of type 9 are also linked in transfer line H-93-33.

\section{Co-segregation of resistance to powdery mildew} and the putative $4 M^{v}$ biochemical markers

We have previously described the joint inheritance of protein marker U-1, associated with addition lines of 

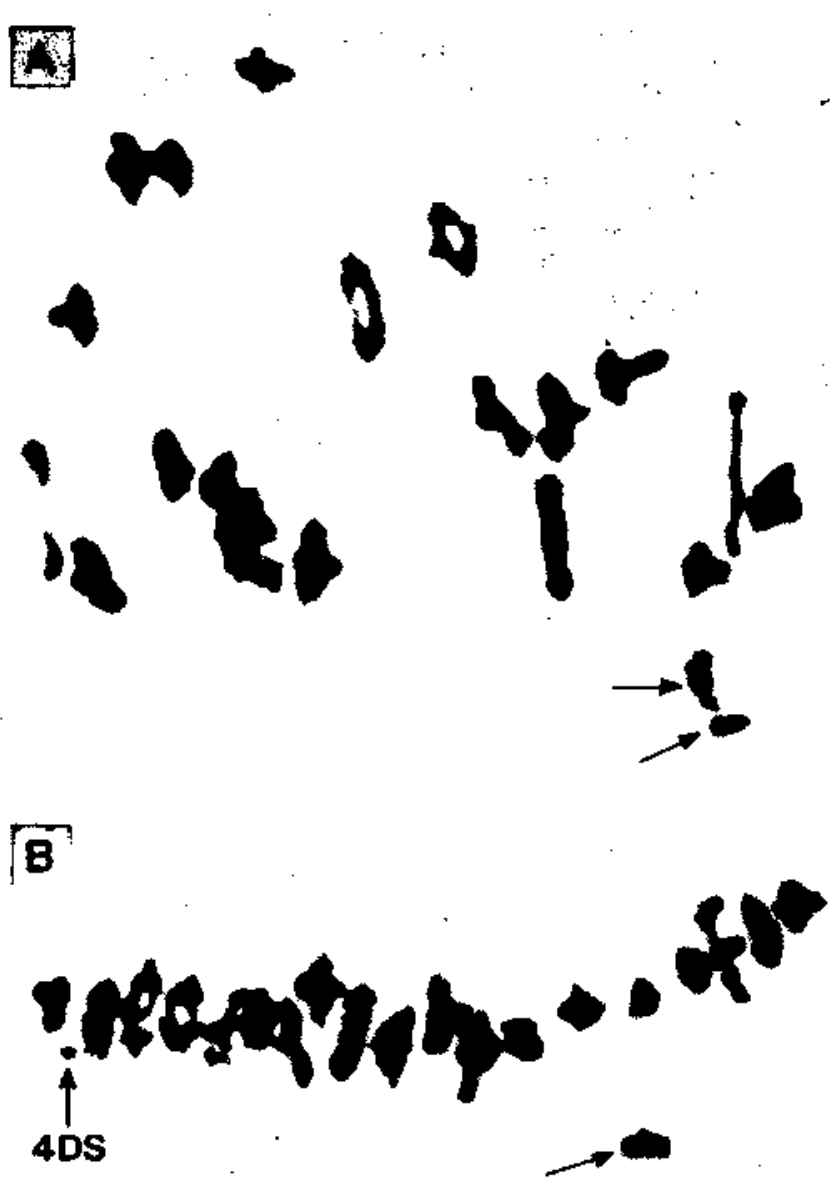

Fig. 3. A Giemsa C-banding of meiotic chromosomes from the hybrids of H-93-33 with $T$. aestivum cv. "Almatense" H-10-15 and $B$ with the 4DS ditelosomic line from T. aestivum cv. "Chinese Spring". Unpaired univalents are indicated with arrows

type 7, and resistance to powdery mildew (Erysiphe graminis) in lines H-93-8 and H-93-35 (Delibes et al. 1987). Line H-93-33 was also resistant to the same inocula of Erysiphe graminis like the other two lines but did not carry protein $\mathrm{U}-1$, which suggested that the resistance gene had been integrated into a wheat chromosome by recombination (Delibes et al. 1987). In the course of the present experiments, plants from the $\mathrm{F} 2(\mathrm{H}-93-33 \times T$. aestivum $\mathrm{H}-10-15$ ) underwent a strong natural infection with $E$. graminis, and the progeny of the $F 2$ plants was tested for the phosphatase isozyme marker. The unexpected linkage of resistance with the biochemical chromosome marker (Table 1) indicates either that two resistance genes are present in two different $\mathrm{M}^{\mathrm{v}}$ chromosomes, or that an unlikely rearrangement has occurred between two unrelated $\mathbf{M}^{\mathrm{v}}$ chromosomes.

\section{Cytological evidence}

Meiosis of the hybrid between line $\mathrm{H}-93-33$ and the recipient $T$. aestivum $\mathrm{H}-10-15$ was investigated using the
Giemsa C-banding technique. Two univalents, one nonbanded and the other heavily banded, were consistently present in all cells examined (Fig. 3A). Similarly, the heavily-banded chromosome, together with the 4DS telosome, appeared consistently unpaired in cells of the hybrid with the 4DS ditelomic line from cv. "Chinese Spring" (Fig. 3B). The non-banded univalent would correspond to chromosome $4 \mathrm{D}$, which is in line with the known lack of susceptibility to Giemsa C-banding of D chromosomes, and the heavily banded chromosome would therefore correspond to chromosome $4 \mathrm{M}^{\mathrm{v}}$, thus confirming the characterization of type 9 addition line and transfer line H-93-33.

Acknowledgements. We acknowledge technical assistance from J. Garcia and L. Lamoneda, and financial support from the Comision Interministerial de Ciencia y Tecnologia (grant BT87-001).

\section{References}

Bennetzen JL, Swanson J, Taylor WC, Freeling M (1984) DNA insertion in the first intron of maize Adh1 affects message levels: cloning of progenitor and mutant Adh1 alleles. Proc Natl Acad Sci USA 81:4125-4128

Brewer GJ (1970) An introduction to isozyme techniques. Academic Press, New York

Brewer GJ, Sing CF, Sears ER (1969) Studies of isozyme patterns in nullisomic tetrasomic combinations of hexaploid wheat. Genetics 64:1224-1229

Delibes A, Garcia-Olmedo F (1973) Biochemical evidence of gene transfer from the $\mathrm{M}^{v}$ genome of Aegilops ventricosa to hexaploid wheat. In: Sears ER, Sears LMS (eds) Proc 4th Int Wheat Genet Symp Columbia Mo, pp 161-166

Delibes A, Dosba F, Doussinault G, Garcia-Olmedo F, Sanchez-Monge R (1977a) Resistance to eyespot (Cercosporella herpotrichoides) and distribution of biochemical markers in hexaploid lines derived from a double cross (Triticum turgidum $\times$ Aegilops ventricosa) $\times T$. aestivum. In: Sanchez-Monge E, García-Olmedo F (eds) Interspecific hybridization in plant breeding, Proc 8th Congr EUCARPIA, Madrid, pp 91-97

Delibes A, Sanchez-Monge R, García-Olmedo F (1977 b) Biochemical and cytological studies of genetic transfer from the $\mathrm{M}^{v}$ genome of Aegilops ventricosa into hexaploid wheat. In: Sanchez-Monge E, García-Olmedo F (eds) Interspecific hybridization in plant breeding, Proc 8th Congr EUCARPIA, Madrid, pp 81-89

Delibes A, Otero C, García-Olmedo F, Dosba F (1981) Biochemical markers associated with two $\mathbf{M}^{v}$ chromosomes from Aegilops ventricosa in wheat-Aegilops addition lines. Theor Appl Genet 60:5-10

Delibes A. Lopez-Braña I, Mena M, García-Olmedo F (1987) Genetic transfer of resistance of powdery mildew and of an associated biochemical marker from Aegilops ventricosa to hexaploid wheat. Theor Appl Genet 73:605-608

Dosba F (1985) Méthodologie du transfert des genes d'Aegilops ventricosa a Triticum aestivum: analyse cytogénétique d'hybrides interspécifiques et étude de lignees d'addition blèaegilops. These d'Etat, Université de Paris-Sud, France

Dosba F, Doussinault G (1977) Introduction into wheat of the resistance to eyespot in Aegilops ventricosa. In: Sanchez- 
Monge E, Garcia-Olmedo F (eds) Interspecific hybridization in plant breeding, Proc 8th Congr EUCARPIA, Madrid, pp 99-107

Dosba F, Doussinault G (1978) Création de lignées de Blé présentant les caractéristiques agronomiques favorables d'Aegilops ventricosa. Ann Amelior Plant 28:27-44

Dosba F, Doussinault G, Rivoal R (1978) Extraction identification and utilization of the addition lines. $T$. aestivumAe, ventricosa. In: Ramanujan \$ (ed) Proc 5th int Wheat Genet Symp, New Delhi, pp 332-337

Doussinault G, Delibes A, Sanchez-Monge R, Garcia-Olmedo $F$ (1983) Transfer of a dominant gene for resistance to eyespot disease from a wild grass to hexaploid wheat. Nature 303:698-700

Feinberg AP, Vogelstein B (1983) A technique for radiolabeling DNA restriction endonuclease fragments to high specific activity. Anal Biochem 132:6-13
Garcia-Olmedo F, Delibes A, Sanchez-Monge R (1984) Transfer of resistance to eyespot disease from Aegilops ventricosa to wheat. Vorträ Pflanzenzüchtg 6:156-168

Hart GE (1970) Evidence for triplicate genes for alcohol dehydrogenase in hexaploid wheat. Proc Natl Acad Sci USA 66:1136-1141

Maniatis T, Fritsch EF, Sambrook J (1982) Molecular cloning: a laboratory manual. Cold Spring Harbor Laboratory Press, Cold Spring Harbor/NY

Murray MG, Thompson WF (1980) Rapid isolation of high molecular weight plant DNA. Nucleic Acids Res $8: 4321-4325$

Sprague R (1936) Relative susceptibility of eertain species of gramineae to Cercosporella herpotrichoides. I Agric Res $53: 659-670$ 